IRA-International Journal of Management \& Social Sciences

ISSN 2455-2267; Vol.13, Issue 03 (December, 2018)

Pg. no. 72-83.

Institute of Research Advances

http://research-advances.org/index.php/RAJMSS

Institute of

Research

Advances

\title{
Influence of Women Participation on Sustainability of Indigenous Chicken Value Chain Project in Kapseret Sub - County, Uasin Gishu County, Kenya
}

\author{
Soy Cherotich ${ }^{1 \#}$ and Yona Sakaja ${ }^{2}$ \\ ${ }^{1,2}$ University of Nairobi, Kenya. \\ \#corresponding author. \\ Type of Review: Peer Reviewed. \\ DOl: http://dx.doi.org/10.21013/jmss.v13.n3.p1
}

How to cite this paper:
Cherotich, S., Sakaja, Y. (2018). Influence of Women Participation on Sustainability of
Indigenous Chicken Value Chain Project in Kapseret Sub - County, Uasin Gishu County, Kenya.
IRA-International Journal of Management \& Social Sciences (ISSN 2455-2267), 13(3), 72-83.
doi:http://dx.doi.org/10.21013/jmss.v13.n3.p1

(C) Institute of Research Advances.

\section{(cc) EY-NC}

This work is licensed under a Creative Commons Attribution-Non Commercial 4.0 International License subject to proper citation to the publication source of the work.

Disclaimer: The scholarly papers as reviewed and published by the Institute of Research Advances (IRA) are the views and opinions of their respective authors and are not the views or opinions of the IRA. The IRA disclaims of any harm or loss caused due to the published content to any party.

Institute of Research Advances is an institutional publisher member of Publishers International Linking Association Inc. (PILA-CrossRef), USA. The institute is an institutional signatory to the Budapest Open Access Initiative, Hungary advocating the open access of scientific and scholarly knowledge. The Institute is a registered content provider under Open Access Initiative Protocol for Metadata Harvesting (OAI-PMH).

The journal is indexed \& included in WorldCat Discovery Service (USA), CrossRef Metadata Search (USA), WorldCat (USA), OCLC (USA), Open J-Gate (India), EZB (Germany) Scilit (Switzerland), Airiti (China), Bielefeld Academic Search Engine (BASE) of Bielefeld University, Germany, PKP Index of Simon Fraser University, Canada. 


\begin{abstract}
The purpose of this study was to establish the influence of women participation on sustainability of indigenous chicken value chain project in Kapseret sub county, Uasin Gishu County, Kenya. Due to this fact of lack of involvement of women in project participation, some projects have failed to meet the required goals thus not being able to attain sustainability. The objectives to be addressed in study were; to examine the influence of interactive participation among women on sustainability of indigenous chicken Value Chain Project implemented in Kapseret sub county, Uasin Gishu County Kenya, to determine the influence of capacity building among women on sustainability of Indigenous chicken Value Chain Project in Kapseret sub county, Uasin Gishu, Kenya, to identify the influence of financial mobilization among the women on sustainability of Indigenous Chicken Value Chain project in Kapseret Sub County, Uasin Gishu County, Kenya, to determine how Market accessibility among women influences sustainability of indigenous chicken value chain project in Kapseret sub county, Uasin Gishu county, Kenya. The research design that was used by the study was descriptive survey design. The target population of 345 respondents was used, which provided a sample size of 181 respondents obtained by using Krejcie and Morgan sample determination Table. The researcher employed stratified simple random sampling while selecting the women groups proportionally. Questionnaires and interviews were used as the main data collection instruments. Validity was tested by scrutinizing the research instrument with the supervisor and help from other university lecturers. Data analysis was done by the use of descriptive statistics aided by Statistical Package for Social Scientist (SPSS) tool of analysis and the results were presented in frequency distribution table. Qualitative data was analyzed using content analysis and presented in statements forms. The study found that participation of women in various activities influenced sustainability of the indigenous Chicken value chain project. In conclusion it shows that interactive participation was agreed upon by majority of the members to be an ingredient that enhances sustainability of their projects. Majority of the respondents mentioned to have been trained and it contributed significantly to productivity levels and through meetings, viable financial structures and enterprise performance are established in projects.
\end{abstract}

Key words: Women Participation, Sustainability, Indigenous Chicken, Value Chain, Uasin Gishu County, Kenya

\title{
Introduction
}

The 2013 Human Development Report recommends that to walk in the human development pathway, people should engage fully in activities that reform the lives and they should be able to take part in policy making procedure and consequences. The significance of gender equality, women's empowerment and the recognition of women's rights in attaining sustainable advance has been more and more familiar in modern decades (Barker, 2005).

Further, United Nation forum on Women in the year 2014 reported that around is growing indication of the synergies amid gender parity, on the one pointer, and economic, social and environmental sustainability, on the former. For example, once women have better voice and involvement in public administration, public assets are additional likely to be owed on the way to investments in social development significances, as well as child health, nutrition and right of entry to employment (Chattopadhyay \& Duflo, 2004). Confirming women's right of entry to and controller over agricultural assets and creative resources is significant for realizing food security and sustainable livelihoods that remained rendering to Food and Agriculture Organization of the United Nations (FAO) in year 2011. Women's information, agency and joint action are central to discovery, representing and building more carefully, on a social basis and environmentally sustainable trails to accomplish local landscapes; acclimatize to climate change; yield and admission food; and safe sustainable water, sanitation and dynamism services (Chattopadhyay \& Duflo, 2004).

The a number of national, regional and international agreements and credentials underline that assisting the population, irrespective of gender to aggressively contribute in social and economic well-being is precarious for long-term and sustainable development of in the least society. It has turn out to be a situation to empower women by creation unquestionable that their starring role is maximum accomplished. As a consequence, it is recognized that Self Help Groups (SHGs) are wastefully empowered over and done with macro-economic policy. Macro-economic effect gender disparity and gender dissimilarity effect macro-economic consequences (World Banking, 2009). Subsequent anywhere the money originates from and anywhere it drives, budgets define how group funds are elevated, how they are castoff and who aids from them. Improved indication point out that gender equality underwrites to poverty decrease and sustainable development (UNDP, 2008). 
Women participation is recognized as one and only of the significant essential elements of poverty decline and as a main development aid objective. Yet women contribution in prescribed political assemblies and developments, where resolutions on the subject of the usage of societal resources made by together men and women folk are ready, leftovers inconsequential. During the course of the world, women have less opportunity to participate either in development or leadership role (United Nations [UN]. 2010). This is despite people having a right to development through participation rendering to United Nations Commission for Human Rights (UNCHR) in the year 2010 which conditions that, the right to growth is an inalienable social accurate by virtue of which each social being and all inhabits are eligible to take part in, subsidize to, and delight in economic, social, cultural and political enlargement in which all human rights and important freedoms can be completely comprehended (Buchy, Ross \& Proctor, 2000). Sustainable projects have the capacity to achieve their goals, continue with their principles and efforts to the extent of meeting the outcome (US Department of Labour, 2010). Many project beneficiaries confuse the fact that sustainability is about acquiring resources to continue operation after the grant period. A precise meaning of sustainability is to ensure the goals of the project are actualized through various programs which concur with people's needs (US Department of Labour, 2010). Transversely the diverse Africa states, women have set up right to take significant parts in the socio-Economic growth of their civilizations. The influence prepared by African women in the providing of both monetary and social amenities is equivalent (Abimbola, 2011).

In unindustrialized countries, Kenya being amongst, mobilization of the deprived persons in self-help groups has been stared as method of establishing communities to yield inventiveness of their own expansion activities. In Western province, these individuals are likewise very communal amongst rural and urban societies and have remained animation for a long-lasting time. They have continued extensively used by growth actors such as administrative and non- governmental administrations as a technique of mobilizing persons for the determinations of tumbling deficiency levels thus carrying development to the persons both informally and economically (Nyanchama, 2016).

Sustainability of Indigenous Chicken value chain project among women has been a great challenge in Kapseret Sub County, Uasin Gishu, Kenya. This is because women are discriminated from cradle to grave and even before birth. In the family, the participants are ruled by a set of standards and practices advanced by the head of the home who calisthenics power, authority and governor above the followers. Women are recognized to produce $80 \%$ of the food manufactured in Africa and nonetheless few are permissible even to possess land (Roy, Haque, Jannat, Ali \& Khan, 2017). Subsequently men take right to use and controller over resources, their part is evidently distinct as bread winners and women folk are theoretical to restrain themselves to the starring role of home makers. Right of entry to and control of industrious resources like land, farm tools and contributions is male controlled (Cuthill, 2010). Consequently, sustainable involvements in the direction of addressing women's applied and strategic desires are important.

From this point of view accompanied with the various studies done by various scholars, the need to look at the participation of women on sustainability of project was necessary to look into especially with concerns on the indigenous chicken value chain project in Kapseret sub - county, Uasin Gishu County, Kenya.

\section{Research Methodology}

This study adopted a descriptive survey design with both non-quantifiable and quantifiable characteristics; the design was the best and applicable to the study because according to Kothari (2004) a descriptive survey is to define evidences and features in relation to a different, group or condition. The design was also picked based on Lokesh (1984) declaration that descriptive survey studies are intended to acquire relevant and detailed data relating to the position of phenomena and on every occasion possible to magnet usable all-purpose deductions from the evidences revealed.

The target population was 345 respondents who consisted of 5 livestock officers and 300 members (20 chairpersons, 20 treasurers (accounting officers) and other 15 members per group).

The sample size was obtained using Krejcie and Morgan sample determination table (1970 as espoused by Sekaran and Bougie (2010). Krejcie and Morgan (1970) significantly simplified size result by setting a table that confirms a respectable result model. As per the table the sample size of the study is outlined to be 181 respondents. The research did employ a stratified simple random method to get the sample size as of the different categories of the 
population. Sekaran (2014) state that stratified simple random method is a sampling method classified as probability because it permits participants the same likelihoods of being chosen from different categories (strata's).

The study used questionnaires and interview schedules to gather primary data. The questions were designed guided by themes of the study and denotations derived from review of literature on women participation on sustainability of Indigenous Chicken Value chain projects. The choice of the tool was guided by the nature of the data collected, availability of such data as well as the objective of the study. The interview schedule was used to collect data from the livestock officers, and were based on research questions. The interview schedule was chosen because it provided an opportunity for open opinions and clarifications. The questionnaires was used since the study concerned mainly with variables which cannot be observed directly such as views, opinions and the population was literate since the representation were the group leaders.

The questionnaires did use both open and close ended questions. The questionnaire consisted of objects relating the likert scale through the responses reaching from strongly agree, agree, not sure, disagree and strongly disagree on a $1,2,3,4,5$ rating scale. The likert scale stood castoff to examination the arrogance of the accused. The questionnaire did entail of both open- ended and closed ended inquiries to deal chances for comments, proposals and areas of enhancement that wanted type a optimistic change when in the participation of women on the way to sustainability of the projects.

The questionnaire reliability was done with 18 women groups and Sub County agricultural and livestock officers in the sub county using a pretest methodology and the data was analyzed using Statistical Package for Social Scientist (SPSS) to determine the reliability of the tool. The researcher did calculate the internal consistency of the questionnaire by applying Cronbach Alpha coefficient. Alpha coefficient arrays in value from 0 to 1 and cast-off to pronounce the reliability of issues extracted from dichotomous (that is, inquiries with two conceivable responses) and/or multi-point arranged questionnaires or scales (i.e., rating scale: $1=$ poor, $5=$ excellent). The advanced the score, the additional reliable the produced scale is. The study created a reliability assessment of 0.76 from 7 items found after the research instruments. Nunnaly (1978) did specified 0.7 to be a satisfactory reliability coefficient but lesser beginnings are every so regularly cast-off in the literature, (Cronbach, 1951).

The data was gathered, stored and collation was done. Quantitative data originating from questionnaires later fed to the Statistical Package for Social Scientists (SPSS) software for analysis. Descriptive statistics was used to analyze data which include: frequencies, percentages, standard deviation and mean. Qualitative data from interview schedules was analyzed through content analysis and organized based on the emerging themes. Final report was then documented and presented using frequency distribution tables.

\section{Findings}

A sum of 181 questionnaires were presented to chairpersons, treasures, and members but only 164 of them were correctly filled and returned that represented $90.61 \%$ questionnaire response rate. All the three livestock officers were sampled and interviewed successfully that represented $100 \%$ interview response rate. According to Kothari (2010) a response rate of more than $75 \%$ is sufficient to continue with the study.

The study sought to find from the respondents how interactive participation contributes to sustainability of Indigenous Chicken Value chain Project. The respondents were asked questions covering activities they perform, meetings held, and relationship between interactive participation and sustainability.

Respondents were asked qualitatively to state some of the activities they performing. Finds were presented in statement form as follows:

'72(44\%) of the study respondents stated that some of the activities they perform is attending meetings to make decisions related to the project. A significant number 75 (46\%) of the respondents stated that savings is the main activity in which they perform in groups. 40 (24\%) of the respondents mentioned solving disputes and complains as part of the activities performed. A significant few 30(18\%) responded that the main activity is sharing ideas. 
The findings from qualitative data show that the main activities performed by group members is saving contribution and attending meetings to make decisions. The study concurs with Lyons et al., (2001) on main activity of attending meetings who states that interactive participation would lead to empowerment through viable sustainable project ideas implemented.

The research did seek from respondents on the whether they attend to group meetings, if so how frequent do they do so, and if not what are the reasons for not attending such group meetings. Findings to the question were found in table 1 .

Table 1 Group meetings

\begin{tabular}{|c|c|c|c|}
\hline Question & Response & $F(n=164)$ & $\%$ \\
\hline \multirow[t]{3}{*}{ Do you attend meetings? } & Yes & 123 & 75 \\
\hline & No & 41 & 25 \\
\hline & Response & $\mathbf{F}(\mathbf{n}=\mathbf{1 2 3})$ & $\%$ \\
\hline \multirow[t]{6}{*}{ If Yes, how frequent do you hold meetings } & Weekly & 22 & 18 \\
\hline & Fortnight & 20 & 16 \\
\hline & Monthly & 67 & 54 \\
\hline & Quarterly & 10 & 9 \\
\hline & Yearly & 4 & 3 \\
\hline & Response & $F(n=41)$ & $\%$ \\
\hline \multirow{4}{*}{$\begin{array}{l}\text { If No, what are the reasons for not attending } \\
\text { meetings }\end{array}$} & I am busy elsewhere & 9 & 22 \\
\hline & It is waste of time & 11 & 27 \\
\hline & Nothing new in meetings & 13 & 32 \\
\hline & No clear meeting agenda & 8 & 19 \\
\hline
\end{tabular}

Respondents were asked whether they attend group meetings findings showed that 123 (75\%) of them attend meetings while $41(25 \%)$ do not attend group meetings. Among those attending the study asked how frequent they do so. It was established that 22 (18\%) attend on a weekly basis, 20 (16\%) on fortnight, 67 (54\%) on a monthly basis, $10(9 \%)$ stated they attend on a quarterly basis, only $4(3 \%)$ attend meetings yearly. The findings shows that majority of the meetings is conducted on a monthly basis. For those who do not attend the meeting the study did wish to establish reasons for not attending. 9 (22\%) of the respondents stated they were busy elsewhere, $11(27 \%)$ stated it is a waste of time, $13(32 \%)$ stated that there is nothing new in such meetings, while $8(19 \%)$ did state that during such meetings there is no clear meeting agenda. Maina (2013) confirms the findings by mentioning that women participation in meetings depends on the nature of work elsewhere thus affecting the outcome of projects. The researcher sought to establish opinions from different respondents on the relationship between interactive participation and sustainability of the indigenous chicken project. Study findings were indicated in table 2.

Table 2

\begin{tabular}{llll}
\hline Statement & N & Mean & SD \\
\hline $\begin{array}{l}\text { Regular attendance of the meetings by women contributes to sustainable } \\
\text { productive levels in your project. }\end{array}$ & 164 & 4.234 & 1.159 \\
$\begin{array}{l}\text { Ability of the members to meet more often leads to viable group savings } \\
\text { as well as improved production levels of the indigenous chicken. }\end{array}$ & 164 & 3.674 & 0.291
\end{tabular}

as well as improved production levels of the indigenous chicken. 
IRA-International Joumal of Management E' Social Sciences

\begin{tabular}{|c|c|c|c|}
\hline $\begin{array}{l}\text { The group participation in action planning is important in establishment } \\
\text { market structures. }\end{array}$ & 164 & 3.765 & 1.164 \\
\hline $\begin{array}{l}\text { The number of meetings conducted has led group's members to } \\
\text { establish viable group savings. }\end{array}$ & 164 & 4.034 & 0.961 \\
\hline
\end{tabular}

Table 4.4 showed respondents with a (mean=4.234, $\mathrm{SD}=1.59)$ agreed that regular attendance of the meetings by women contributes to sustainable productive levels in their project. The finding is clarified further by Midgley, Hall, Hardiman, \& Narine (1986) in their study on social group dynamics and sustainability explains the need of participative action planning to be useful in the achievement of sustainability by attending open forums. A total of respondents with (mean=3.674, $\mathrm{SD}=0.29)$ stated that ability of the members to meet more often leads to viable group savings as well as improved production levels of the indigenous chicken. Respondents with a (mean=3.765, $\mathrm{SD}=1.16$ ) agreed that group participation in action planning is important in establishment market structures. The finding concurs with McGee (2002) who states that not merely yearn for participatory tactics support project sustainability but it contends that participation yearn for brand projects more proficient and real. Finding showed that respondents with (mean=4.034, $\mathrm{SD}=0.961$ ) agreed that the number of meetings conducted has led group's members to establish viable group savings.

The study further conducted interviews with the livestock officers on whether interactive participation of women during meetings has contributed to productivity levels. Study findings were indicated qualitatively has follows:

'The three livestock managers unanimously agreed that interactive participation directly contributes to positive productivity levels in groups. One livestock officer mentioned the importance of having frequent meeting which enhances bonding and more learning process. The more meetings are held the more information's is shared and useful decisions are made. Further the study through the interview schedule found that during interactive meetings done by group members decisions are made, savings collected, loans paid, references are made, teachings conducted, risk mitigations done, and consultations done.'

The findings from the study both from the group members and livestock officers show the importance of interactive participation in enhancing sustainability of Indigenous chicken value chain project. During frequent meetings held more inputs and information's are shared by the members

The study sought to establish whether capacity building in the group contributes to sustainability of the projects by seeking responses to questions on group trainings and its contributions.

The study did to establish if the respondents have been trained and if so how often have they been trained. Table 3 reports findings on group trainings.

Table 3 Group trainings

\begin{tabular}{llll}
\hline Question & Response & F (n=164) & \% \\
\hline Are you trained? & Yes & 134 & 82 \\
& No & 30 & 18 \\
\cline { 2 - 4 } & Response & $\mathbf{F ~ ( n = 1 3 4 )}$ & $\mathbf{\%}$ \\
How often are you trained? & Rarely & 26 & 19 \\
& Often & 59 & 45 \\
& More often & 38 & 28 \\
& Not at all & 11 & 8
\end{tabular}

Table 3 findings on the question on whether respondents have been trained showed that 134(82\%) have been trained, and $30(18 \%)$ stated that they have not been trained. The findings shows that majority of the respondents have been trained. Study further asked the respondents how often are they been trained findings showed that 26 $(19 \%)$ of respondents stated they are rarely trained, $59(45 \%)$ stated often, $38(28 \%)$ stated more often, while 11 $(8 \%)$ stated they have never been trained at all. 
The respondents were asked to respond from various the following on the extent to which trainings contribute to productivity levels. Study findings were indicated in table 4.

\section{Table 4 Trainings and productivity}

\begin{tabular}{|c|c|c|c|}
\hline Responses & $F(n=164)$ & Mean & SD \\
\hline The group member's participation in trainings improves productivity levels. & 164 & 4.342 & 1.099 \\
\hline $\begin{array}{l}\text { Frequency of training has made it possible for knowledge disbursement thus } \\
\text { assisting the groups in knowing which market structures to target and sell } \\
\text { their product. }\end{array}$ & 164 & 3.013 & 0.978 \\
\hline $\begin{array}{l}\text { The nature of trainings conducted has led group's members to establish } \\
\text { viable financial structures. }\end{array}$ & 164 & 3.834 & 1.059 \\
\hline $\begin{array}{l}\text { Trainings and stakeholder involvement in the within the scope of the project } \\
\text { has resulted sustainability of the project. }\end{array}$ & 164 & 4.234 & 0.885 \\
\hline
\end{tabular}

Table 4 shows that respondents with a (mean=4.342, $\mathrm{SD}=1.099)$ agreed that the group member's participation in trainings improves productivity levels. Gruber (2010) argues in support to the findings that community grounded capacity building assists to improve a moral intellect of obligation if the audiences are provided with relevant valuable trainings. Respondents with a (mean=3.013, SD=0.978) gave an average comment that frequency of training has made it possible for knowledge disbursement thus assisting the groups in knowing which market structures to target and sell their product. The findings contradicts findings by Ameeq et al. (2013) who positions that exercise is learning procedure that encompasses the attainment of information, improving of skills, conceptions, and rubrics or altering of attitudes and manners to improve the performance of persons inside their employed surroundings.

Respondents with (mean=3.834, $\mathrm{SD}=1.059$ ) agreed that the nature of trainings conducted has led group's members to establish viable financial structures. The findings concurs with Storey (1999) on a study related to subjects of addition, contribution and enablement in rural expansion Skills are definite as expertise, adept ability, ability in responsibility approximately, deftness and sensitivity facilitated by trainings. Respondents with a (mean=4.234, $\mathrm{SD}=0.885$ ) agreed that trainings and stakeholder involvement in the within the scope of the project has resulted sustainability of the project. Akanji, 2006; Cheston \& Kuhn, 2002; Kuzilwa, 2005) confirms the outcomes that skillfulness drill and tertiary schooling have constructive consequence on enterprise presentation in projects.

The livestock officers were asked through the interview on the nature of capacity building and sustainability of group projects Study findings were indicated as follows:

'Three of the livestock officers agreed that trainings conducted are valuable to group members. One livestock officer stated that trainings through demonstrations and field trips are more effective in building capacity among the members. Some of aspects done during trainings include: methods of rearing chicken, treatment methods, management of finances, and sourcing of inputs. Three of the livestock officers agreed that capacity building is the main contributor to project sustainability.'

The findings established that capacity building's has the main contributor sustainable projects by the members. The researcher did seek to determine how financial mobilization contributes sustainability of indigenous chicken projects. Respondents were asked questions on the sources, accessibility of financial sources and extent to which credit sources facilitate productivity.

The study did establish from the respondents the various sources of finances and the various sources in which they can obtain finances. Reported findings were in table 5. 
IRA-International Journal of Management E' Social Sciences

Table 5 Financial mobilization

\begin{tabular}{llll}
\hline Questions & Responses & F(n=164) & \% \\
\hline What sources of finances do you have for your & Table banking & 98 & 60 \\
project? & Merry -Go- Round & 42 & 26 \\
& Grants & 6 & 4 \\
& Banks loans & 10 & 6 \\
& Small and Micro enterprise & 8 & 5 \\
& Institutions & & \\
\cline { 2 - 4 } & Rarely & 8 & 5 \\
How often do you access these financial & Often & 102 & 62 \\
resources? & More often & 44 & 27 \\
& Not at all & 10 & 6 \\
\hline \hline
\end{tabular}

Table 5 reports findings on the responses on the sources of finances were 98(60\%) of the respondents stated that table banking is their source, $42(26 \%)$ of respondents stated merry go round, $6(4 \%)$ stated it comes from grants, 10 $(6 \%)$ stated it comes from bank loans, 8 (5\%) of respondents stated that it comes from small and micro enterprise institutions. The findings showed that table banking is the dominant source of finances for the group members. Further the study wanted to establish the extent to which they access financial resources. Findings showed that 8 (5\%) stated rarely, 102(62\%) stated more often, 44(27\%) stated more often, while $10(6 \%)$ did state not at all. From the finding the study can conclude that group members often get finances when they need them.

Respondents were asked to state the extent to which credit sources accessed by group members contribute to productivity levels findings to the various statements were presented in table 6 .

Table 6 Credit sources and productivity levels

\begin{tabular}{lllll}
\hline Responses & F (n=164) & Mean & Variance & SD \\
\hline $\begin{array}{l}\text { More credit sources accessed by women have improved } \\
\text { productivity level of the projects. }\end{array}$ & 164 & 4.467 & 1.004 & 1.002 \\
$\begin{array}{l}\text { The nature of group savings generated by members has } \\
\text { The }\end{array}$ & & 4.567 & 0.123 & 0.351
\end{tabular}

led to viable savings in the group hence improved

productivity levels.

Table 6 shows that respondents with a (mean=4.467, SD=1.002) agreed that more credit sources accessed by women have improved productivity level of the projects. The study found that Claridge (2004) on journal study of designing social capital sensitive participation methodologies states that developing a plan or strategy for financial mobilization can lead to creative efforts in using your own local assets to gain support for your organization.

Study found that respondents with (mean $=4.567, \mathrm{SD}=0.351$ ) agreed that the nature of group savings generated by members has led to viable savings in the group hence improved productivity levels. The finding is supported by the results of interviews conducted to livestock officers. The results were qualitatively analyzed as follows:

'Three of the livestock managers were in agreement that group mobilization of finances is critical in coming up with viable saving plan for their group. They stated that group members need to formulate good policies that encourage members to collect save and share finances effectively.

The study established from the findings that financial mobilization is an important factor in enhancing sustainability of projects. That was supported by both group members and livestock officers' responses. 
The study did want to establish the how market accessibility contributes to sustainability of projects. Respondents were asked questions on where they sell indigenous chicken, frequency of selling the products, methodology of getting market information, ways of determining prices of the product, and availability of the market.

The study sought to establish from the respondents how they sell their indigenous chicken findings were qualitatively summarized as follows:

$26(16 \%)$ of the respondents stated that they sell the chicken to neighbors, 32 (20\%) sell to friends referred to them, 64(39\%) of them stated that they sell the chicken to local markets. Some of the respondents $18(11 \%)$ stated that they sell to businessmen and women who visit their homes. A significant number of respondents $24(15 \%)$ stated that group marketing is the channel of selling the indigenous chicken.'

The study found the dominant selling point for selling chicken by group members is through the local market.

\subsubsection{Market accessibility and information}

Respondents were asked several questions in reference to frequency of selling their products, how they access market information and how they can determine the prices of the products. Study findings were indicated in table 7.

Table 7 Market accessibility and information

\begin{tabular}{|c|c|c|c|}
\hline Questions & Responses & $\mathbf{F}(\mathbf{n}=164)$ & $\%$ \\
\hline \multirow[t]{4}{*}{ How often do you sell your product? } & Rarely & 42 & 26 \\
\hline & Often & 88 & 54 \\
\hline & More often & 24 & 15 \\
\hline & Not at all & 10 & 6 \\
\hline \multirow[t]{4}{*}{ Where do you get market information? } & Customers & 14 & 9 \\
\hline & Extension-service providers & 16 & 10 \\
\hline & Producers( farmers ) & 126 & 77 \\
\hline & SMS services & 8 & 5 \\
\hline \multirow[t]{2}{*}{ Who determines the prices of your product? } & Seller & 123 & 75 \\
\hline & Buyer & 41 & 25 \\
\hline
\end{tabular}

Respondents were asked how often they sell their products. Findings in table 7 showed that 42 (26\%) stated that it is rarely for them to sell their products, 88(54\%) stated often, 24(15\%) stated more often, and $10(6 \%)$ stated that they do not sell at all. The findings have shown that often they sell products. Respondents were further asked to indicate the sources of market information originates from the customers 14(9\%), 16(10\%) stated they obtain from extension service providers, $126(77 \%)$ stated they obtain information from farmers, while a number $8(5 \%)$ stated they obtain from SMS services. The findings show that farmers obtain information from producers or farmers. Findings in table 4.9 showed that $123(75 \%)$ of the respondents stated that the sellers are the ones who determine the prices, while $41(25 \%)$ of the respondents stated that the buyers are the ones who determine the prices of their products. Findings show it is the sellers who determine the prices of the products.

Respondents were asked to indicate the extent to which the market can contribute to productivity levels of their project. Findings for the different responses were presented in table 8 . 
IRA-International Journal of Management छ' Social Sciences

Table 8 Market accessibility and productivity levels

\begin{tabular}{|c|c|c|c|c|}
\hline Statements & $\mathbf{N}$ & Mean & Variance & SD \\
\hline $\begin{array}{l}\text { The women groups have well established distribution channels } \\
\text { that contribute to proper market structures leading to improved } \\
\text { productivity levels. }\end{array}$ & 164 & 4.456 & 1.056 & 1.028 \\
\hline $\begin{array}{l}\text { Availability of market information has led to improved } \\
\text { production levels. }\end{array}$ & 164 & 3.876 & 0.956 & 0.977 \\
\hline $\begin{array}{l}\text { Availability of formal market structures has led to sustainable } \\
\text { indigenous chicken value chain project. }\end{array}$ & 164 & 4.023 & 1.004 & 1.002 \\
\hline Determination of prices of the products by women has led to & 164 & 3.924 & 1.234 & 1.111 \\
\hline
\end{tabular}

viable group savings as well as increased production levels and consistency in the supply in the market

Findings as per table 8 showed respondents with (mean=4.456, $\mathrm{SD}=1.028)$ agreeing that women groups have well established distribution channels that contribute to proper market structures leading to improved productivity levels. The findings concur with Burkett (2017) who states that the rationale for having women participate in creating market for their produce helps in empowering individuals to ensure they are sustainable and increases productivity. Respondents with (mean=3.876, mean=0.977) agreed that availability of market information has led to improved production levels. The findings is true with Muthoka (2012) who says there are varying underlying motivations for pursuing SMEs self-sustainability with participation in linkage creations by sharing market information. Availability of formal market structures has led to sustainable indigenous chicken value chain project this is according to respondents with (mean=4.023, SD=1.002) who agreed with it. In addition respondents with (mean=3.924, $\mathrm{SD}=1.111$ ) agreed with the statement that determination of prices of the products by women has led to viable group savings as well as increased production levels and consistency in the supply in the market.

The study further sought responses from livestock officers through interviews on the relations between market accessibility and sustainability of projects. Study findings were indicated as follows:

'Three of the livestock officer did strongly agree that market accessibility is important in ensuring sustainable project. They stated that group members should look for markets for their products, set distribution channels, and set competitive prices. They both agreed that having market accessibility contributes to sustainable groups.'

The study established from the responses from the group members and livestock officers that market accessibility is an important ingredient in sustainability of group projects.

\section{Conclusion}

The findings showed that the group members have lasted long to understand how the group is performing, in addition majority of them agreed to have participated in the project. The study found that the main activity in groups were savings contribution and decisions making. The study further concluded that regular attendance is the key element in ensuring sustainable project through regular viable savings. More findings showed that interactive participation was agreed upon to be an ingredient that enhances sustainability of their projects. Majority of the respondents mentioned to have been trained and that contributes significantly to productivity levels. Through meetings the group members agreed that viable financial structures and enterprise performance is evidenced in projects.

The study found out that financial mobilization to be an important factor in enhancing sustainability of a project. Through group savings the members are able to accumulate sufficient financial resources. The study in addition found that market accessibility is an important factor in ensuring sustainability of group funded projects. 


\section{Recommendations}

The study recommends the following

- Group members should implement participative initiatives to ensure that their projects are sustainable in the long run. Some of the aspects that require to be integrated include financial mobilization, capacity building and market accessibility.

- Institutions and firms intending to sponsor projects should take consideration of participation as part of their policies in order to ensure sustainability of the sponsored projects.

- Relevant authorities can use the findings of the study in addressing the key challenges that they might encountered while developing strategies towards the sustainability of development projects in the community.

\section{References}

[1]. Agarwal, B. (2001). Participatory exclusions, community forestry, and gender: An analysis for South Asia and a conceptual framework. World development, 29(10), 1623-1648.

[2]. Akanji, O. O. (2006). Microfinance as a strategy for poverty reduction. Central Bank of Nigeria Economic and Financial Review, 39(4), 98-112.

[3]. Alkire, S., Meinzen-Dick, R., Peterman, A., Quisumbing, A., Seymour, G., \&Vaz, A. (2013). The women's empowerment in agriculture index. World Development, 52, 71-91.

[4]. Barker, A. (2005). Capacity building for sustainability: towards community development in coastal Scotland. Journal of Environmental Management, 75(1), 11-19.

[5]. Bell, S., \& Morse, S. (2013). Measuring sustainability: Learning from doing. Routledge.

[6]. Buchanan, S. (2016). Transforming conflict through social and economic development: practice and policy lessons from Northern Ireland and the Border Counties. Oxford University Press.

[7]. Buchy, M., Ross, H., \& Proctor, W. (2000). Enhancing the information base on participatory approaches in Australian natural resource management. Land and Water Australia (ed.) Natural Resources ManagementPeople and Policy, Land and Water Australia, Canberra, 1-78.

[8]. Burkett, H. (2017). Transforming to a Sustainable Learning Organization. Main. Retrieved 20 March 2018, from https://www.td.org/insights/transforming-to-a-sustainable-learning-organization

[9]. Chamala, S. (1995). Overview of participative action approaches in Australian land and water management. $S$. Chamala and K. Keith, Participative Approaches For Landcare, Perspectives, Policies, Programs, Australian Academic Press, Brisbane, Australia, 5-42.

[10]. Chattopadhyay, R., \&Duflo, E. (2004). Women as policy makers: Evidence from a randomized policy experiment in India. Econometrica, 72(5), 1409-1443.

[11]. Claridge, T. (2004). Designing social capital sensitive participation methodologies. Journal of Conflict resolution, 580-600.

[12]. Cuthill, M. (2010). Strengthening the 'social' sustainable development: Developing a conceptual framework for social sustainability in a rapid urban growth region in Australia. Sustainable Development, 18(6), 362-373.

[13]. Ferdousi, F. (2015). Impact of microfinance on sustainable entrepreneurship development. Development Studies Research, 2(1), 51-63.

[14]. Gruber, J. S. (2010). Key principles of community-based natural resource management: a synthesis and interpretation of identified effective approaches for managing the commons. Environmental management, 45(1), 52-66.

[15]. Hussein, K. (1995). Participatory ideology and practical development: agency control in a fisheries project, Kariba Lake. Power and Participatory Development. Theory and Practice. Intermediate Technology Publications.

[16]. Kabeer, N. (2001). Conflicts over credit: re-evaluating the empowerment potential of loans to women in rural Bangladesh. World development, 29(1), 63-84.

[17]. Kelly, D. (2001). Community Participation in Rangeland Management: A Report for the Rural Industries Research and Development Corporporation. RIRDC.

[18]. Lane, J. (1995). Non-governmental organizations and participatory development: the concept in theory versus the concept in practice. Power and Participatory Development: Theory and Practice'London: Intermediate Technology Publications.

[19]. Lyons, M., Smuts, C., \& Stephens, A. (2001). Participation, empowerment and sustainability :( How) do the links work? Urban studies, 38(8), 1233-1251.

[20]. Maina, B. M. (2013). Influence of stakeholders' participation on the success of the economic stimulus programme: a case of education projects in Nakuru County, Kenya. Retrieved from. 
[21]. Marks, S. J., \& Davis, J. (2012). Does user participation lead to sense of ownership for rural water systems? Evidence from Kenya. World Development, 40(8), 1569-1576.

[22]. Martínez-Restrepo, S., Ramos-Jaimes, L., Espino, A., Valdivia, M., \&Yancari Cueva, J. (2017). Measuring women's economic empowerment: Lessons from South America.

[23]. Martínez-Restrepo, S., Ramos-Jaimes, L., Espino, A., Valdivia, M., \&Yancari Cueva, J. (2017). Measuring women's economic empowerment: Lessons from South America.

[24]. McGee, R. (2002). Participating in Development, Development Theory and Practice: critical perspective.

[25]. Midgley, J., Hall, A., Hardiman, M., \&Narine, D. (1986). Community participation, social development and the state. Methuen.

[26]. Mkpado, M., \&Arene, C. J. (2007). Effects of democratization of group administration on the sustainability of agricultural micro credit groups in Nigeria. International Journal of Rural Studies, 14(2).

[27]. Molund, S. \&Schill, G. (2004). Looking back, moving forward: SIDA evaluation manual. Stockholm: SIDA.

[28]. MUTHOKA, J. M. (2012). EFFECT OF MICROFINANCE ON FINANCIAL SUSTAINABILITY OF SMALL AND MEDIUM ENTERPRISES IN NAIROBI EAST DISTRICT (Doctoral dissertation, SCHOOL OF BUSINESS, UNIVERSITY OF NAIROBI).

[29]. Ndekha, A., Hansen, E. H., Mølgaard, P., Woelk, G., \&Furu, P. (2003). Community participation as an interactive learning process: experiences from a schistosomiasis control project in Zimbabwe. ActaTropica, 85(3), 325-338.

[30]. Nelson, N., \& Wright, S. (1995). Power and participatory development: Theory and practice. ITDG Publishing.

[31]. Nelson, S., Sisto, I., Crowley, E., \& Villarreal, M. (2012). Women in Agriculture: Closing the Gender Gap for Development1. Feeding a Thirsty World, 25.

[32]. Nyanchama, G. (2016). Influence of Self Help Groups On Economic Empowerment Of Women In Rongo Sub County, Migori County, Kenya (Masters). University Of Nairobi.

[33]. Ochunga, F. O., \&Awiti, L. H. (2017). Influence of Stakeholder Participation on Sustainability of Community Development Projects Implemented by Plan International in Homa Bay Town Sub-County, Kenya. International Journal of Academic Research in Business and Social Sciences, 7(4), 375-400.

[34]. Pelling, M. (1998). Participation, social capital and vulnerability to urban flooding in Guyana. Journal of International Development, 10(4), 469-486.

[35]. Pocol, C. B., Arion, F. H., Dumitras, D. E., Jitea, I. M., Muresan, I. C., \& Mihai, M. (2017). THE COMPREHENSION AND STUDY OF THE CONCEPTUAL SIGNIFICANCE OF ${ }^{e}$ SUSTAINABILITY'IN AGRICULTURE AND FOOD PRODUCTION AT UNIVERSITY LEVEL. Agriculture and Food.

[36]. Roy, P. K., Haque, S., Jannat, A., Ali, M., \& Khan, M. S. (2017). Contribution of women to household income and decision making in some selected areas of Mymensingh in Bangladesh. Progressive Agriculture, 28(2), 120129.

[37]. Samhsa. (2016). Capacity Building and Sustainability | SAMHSA. Samhsa.gov. Retrieved 20 March 2018, from https://www.samhsa.gov/capt/tools-learning-resources/capacity-building-sustainability

[38]. Schakel, W., \&Hakhverdian, A. (2018). Ideological congruence and socio-economic inequality. European Political Science Review, 1-25.

[39]. Storey, D. (1999). Issues of integration, participation and empowerment in rural development: the case of LEADER in the Republic of Ireland. Journal of rural studies, 15(3), 307-315.

[40]. Women, U. N. (2014). World Survey on the role of women in development 2014: Gender Equality and Sustainable Development. A report signed by the Secretary General and Executive Director, UN Women.[PDF].

[41]. Xu, Q., Perkins, D. D., \& Chow, J. C. C. (2010). Sense of community, neighboring, and social capital as predictors of local political participation in China. American journal of community psychology, 45(3-4), $259-271$. 